\title{
Environmental restoration and management of the Seco River in Tabasco, Southern coast of the Gulf of Mexico
}

\author{
M. I. Ferrer-Sánchez ${ }^{1}$, R. G. Bautista-Margulis ${ }^{1}$, \\ E. S. López-Hernández ${ }^{1}$, A. Vázquez-Botello ${ }^{2}$, \\ G. López-Ocaña ${ }^{1}$, M. Juárez-García ${ }^{1} \&$ A. A. Ramírez-Alejandre ${ }^{1}$ \\ ${ }^{I}$ The Juarez Autonomous University of Tabasco, Mexico \\ ${ }^{2}$ The National Autonomous University of Mexico, DF, Mexico
}

\begin{abstract}
In the state of Tabasco, Mexico, the main aquatic ecosystems are wastewater receptors coming from domestic and industrial discharges. In this context, the Seco River is an important aquatic system with a high degree of physicochemical and biological pollution. To date, the extent of damage caused to the fishery biodiversity, agriculture and other commercial activities is practically nonexistent. Hence, the objective of this investigation is to study the social and environmental behavior at the surroundings of the Seco River by monitoring and simulating its environmental changes in the period 2000-2003. The Geographical Information System (GIS) Arcview 32 and the ecological model IDRISI 3.2 were employed as a basic computational tool. Also, four sampling stations were strategically installed along the Seco River. The "in situ" measurements indicated high contamination levels, such as: $\mathrm{BOD}_{5}>120 \mathrm{mg} / \mathrm{l}$, DO $<2.1 \mathrm{mg} / 1$ and Salinity $=42,000-50,000 \mathrm{ppm}$. In addition, high metal concentrations $(\mathrm{Cr}, \mathrm{Cd}, \mathrm{Zn}, \mathrm{As}, \mathrm{Pb}, \mathrm{Ni})$ were found to be present during the sediment sampling. The modeling results revealed that great areas of coconut plantations were lost and replaced by pastures in the three-year period. The sediment input became a serious contamination problem by non-point sources due to the increase of non vegetation areas. Therefore, the current study aimed at proposing an environmental restoration of the Seco River and a management state program for the community in the short-term.
\end{abstract}

Keywords: environmental restoration, river pollution, aquatic ecosystem. 


\section{Introduction}

An aquatic ecosystem is any water-based environment in which plants and animals interact with the chemical and physical features of the environment. Aquatic ecosystems are generally divided into two types: the marine ecosystem and the freshwater ecosystem. Marine ecosystems cover over $70 \%$ of the earth's surface, among them: oceans, estuaries, coral reefs and coastal ecosystems. Freshwater ecosystems cover less than $1 \%$ of the earth and are subdivided into lotic (rivers, streams), lentic (lakes, ponds) and wetlands (swamps, marshes, bogs).

In Tabasco, Mexico, rivers and creeks are part of the main aquatic ecosystems that receive wastewater coming from domestic and industrial discharges (point and non-point sources). In this regard, physicochemical and biological pollutants are increasingly generated in continental and coastal lakes located in the southern coast of the Gulf of Mexico. In this sense, the coastal lake system represents about 18,000 acres of surface.

The hydrographic network of Paraíso-Tabasco comprises two systems: 1) "La Albufera" or littoral lake separated from the ocean by a sandy string and, 2) the Mecoacan Lake and the Seco River which end up to the Port of Dos Bocas in the Gulf of Mexico, as shown in Figure 1. The Mecoacan Lake has a great variability of its hydrologic conditions, having a wide range of superficial salinities but a narrow temperature range. Salinity decreases from West to East while the temperature increases slightly in that direction. The average annual ambient temperature is $27^{\circ} \mathrm{C}$, reaching a maximum of $32.5^{\circ} \mathrm{C}$ and a minimum of $22.5^{\circ} \mathrm{C}[1]$.

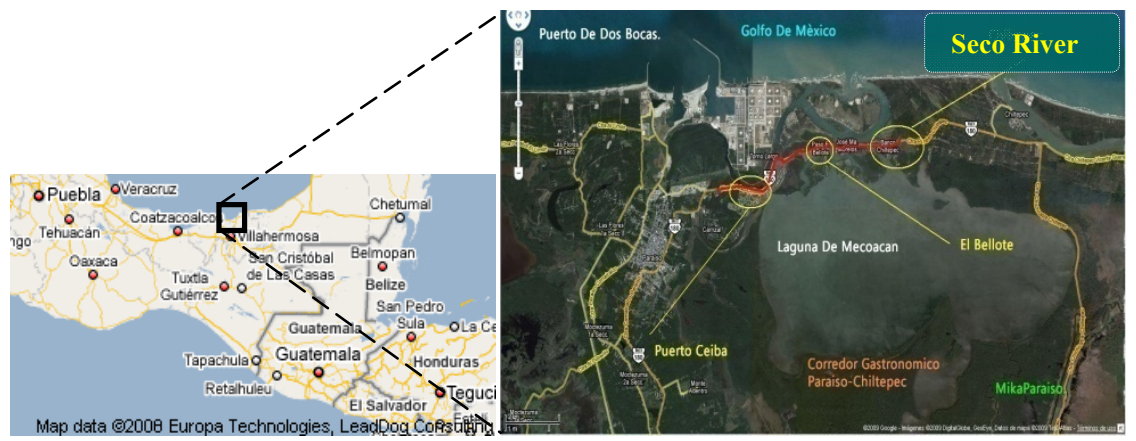

Figure 1: Satellite location of the Seco River in Tabasco, Mexico.

The diagnosis of the environmental impact for the coastal lakes and watersheds of Tabasco indicates the presence of various biophysical components, like: mangrove vegetation Rizophora mangle, Laguncularia racemosa and Avicennia germinans; hydrophytes vegetation of Typha latifolia and other emergent aquatic species, as well as induced pastures associated with mangroves and used for cattle. The agriculture is characterized by land farms of Zea mays, Cucurbita e Ipomea. There is a great extension of perennial 
plantations like Cocus nucifera, and the cattle activities can be either extensive or semi-extensive. Fishery is also practiced on every aquatic environment of this ecosystem $[2,3]$.

In the past, very few hydrobiological studies have been focused on the management and developing techniques directed to increase the productivity, as well as to explain the hydrologic evolution and behavior of these lake systems [4]. Likewise, tridimensional hydrodynamic models have been applied to study the potential effect of the superficial water intake and its influence on the streams, salinity, cyclic transport and pollutants fate [5, 6].

In Latin America, relatively little attention has been given to the social and environmental factors affecting freshwater ecosystems and, therefore, the economic growth and sustainable development of a particular region. Hence a primary directive should be to facilitate the development and application of scientifically sound methods for monitoring and assessing the condition of aquatic ecosystems.

The objective of this investigation was to study the social and environmental behavior at the surroundings of the Seco River by monitoring and simulating its environmental changes in the period 2000-2003. Consequently, an environmental restoration of the Seco River and a management state program for the community in the short-term is intended to be proposed and implemented.

\section{Materials and methods}

\subsection{Biological and physicochemical characterization of the Seco River}

The extent of environmental pollution in the river stream was determined in nine specific sites (Table 1). The selected sampling points were considered as monitoring stations (Figure 2). The main parameters were analyzed according to the NOM-001-SEMARNAT-1996 established in the Mexican environmental legislation [7]. During the experiments, the influent and the effluent were sampled daily to evaluate the efficiency of the treatment system. The samples were analyzed immediately, following the methods and the calibration guidelines suggested by Hach Company [8]. Total coliforms were analyzed by applying the Standard Methods for the Examination of Water and Wastewater [9]. COD was measured using the reflux method [10]; turbidity was measured with a turbidimeter, and $\mathrm{pH}$ with a potentiometer; electrical conductivity was determined using a conductivity bridge; dissolved oxygen by the Winkler method; sedimenting solids, the Imhof cone; total solids, by gravimetry; nitrates, by the $\mathrm{Cd}$ redox method (reduction of cadmium); nitrites, by the diazotization method; and ammoniac nitrogen by the Nessler method. All these methods have been approved for wastewater by the EPA, and Hach equipment was employed. Heavy metal concentrations (i.e., $\mathrm{Cu}, \mathrm{Zn}, \mathrm{As}, \mathrm{Hg}, \mathrm{Cd}, \mathrm{Pb}, \mathrm{Cr}, \mathrm{Ni}$ ) were also measured in situ by spectrophotometry using a Labsun portable multi-parameters water quality analyzer, model Photolab 360 [11]. 
Table 1: Geographical coordinates of the sampling points.

\begin{tabular}{cc}
\hline $\begin{array}{c}\text { Sampling } \\
\text { Point }\end{array}$ & $\begin{array}{c}\text { GPS } \\
\text { (UTM) }\end{array}$ \\
\hline RP001 & $18^{\circ} 23.24^{\prime} \mathrm{N}, 93^{\circ} 14.452^{\prime} \mathrm{W}$ \\
RP002 & $18^{\circ} 23.55^{\prime} \mathrm{N}, 93^{\circ} 13.596^{\prime} \mathrm{W}$ \\
RP003 & $18^{\circ} 23.592^{\prime} \mathrm{N}, 93^{\circ} 13.014^{\prime} \mathrm{W}$ \\
RP004 & $18^{\circ} 23.636^{\prime} \mathrm{N}, 93^{\circ} 12.628^{\prime} \mathrm{W}$ \\
RP005 & $18^{\circ} 24.029^{\prime} \mathrm{N}, 93^{\circ} 12.423^{\prime} \mathrm{W}$ \\
RP006 & $18^{\circ} 24.745^{\prime} \mathrm{N}, 93^{\circ} 12.436^{\prime} \mathrm{W}$ \\
RP007 & $18^{\circ} 25.842^{\prime} \mathrm{N}, 93^{\circ} 11.655^{\prime} \mathrm{W}$ \\
RP008 & $18^{\circ} 24.22^{\prime} \mathrm{N}, 93^{\circ} 12.221^{\prime} \mathrm{W}$ \\
\hline RP009 &
\end{tabular}

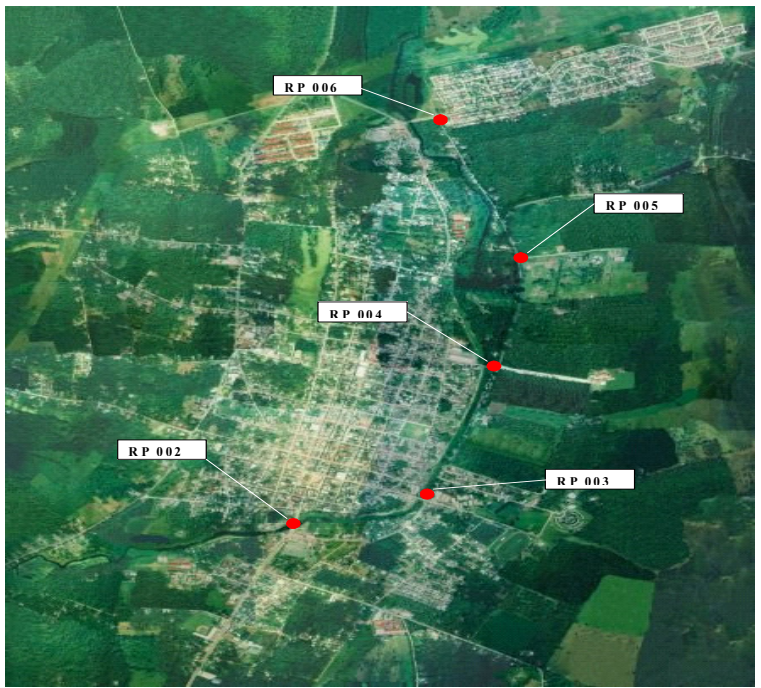

Figure 2: Location of five monitoring stations at the Seco River.

\subsection{Environmental factors and Geographic Information System}

For the application of the Geographic Information System (GIS), various digital images were acquired to get a general overview of the study area. Such images were produced by the satellite system known as LANDSAT for the period 20002003. Geographical and environmental information obtained from previous investigations [11] were employed as "Lay-out" type model with geo-referenced data. In this context, the geographical software "Arcview 3.3" was selected and computed in order to analyze their distribution patterns and characteristics at the spatial and temporal scale. The generated "lay-outs" were displayed for the following: water receptors, ocean waters, main roads, secondary roads, human settlements, industrial areas, off-shore baseline, vegetation, etc. Three 
LANDSAT images were also used for the above mentioned period, having a maximum resolution of $38 \mathrm{~m}$. Each image was made up of various spectral bands $(\mathrm{nm})$ from which the best digital resolution was selected. The application of the Arcview program allowed to identifying the environmental elements that integrate the whole study area. In this sense, a geographical positioning system (GPS) helped at defining specific identified areas on each LANDSAT images during the three years period. The on-field information consisted on gathering the following data: sample identification, site identification, site name, people's name taking the sample, sampling date and time as well as photograph orientation.

\subsection{Environmental restoration and management state program}

Theoretical models based on environmental education and services allowed for the development of a specific socio-environmental model. The input parameters for this model required the use of GIS, the application of the ecological model IDRISI and the physicochemical and biological characterization (as described above). The new computational approach gave rise to set-up future environmental sceneries, relying on systematic evaluations from historical images in certain periods of time. Previous investigations applying for the Arcview program and IDRISI model have also been reported elsewhere [12-14]. Likewise, an integrated-environmental strategy may be developed and implemented as a new fundamental educating model which seeks both social and political participation of the citizens and/or communities in terms of sustainability. Therefore, the current study aimed at proposing an environmental restoration of the Seco River and a management state program for the community in the short-term.

\section{Results and discussion}

From the physicochemical and biological characterization, the field results showed a high contamination level of the Seco River. In the case of $\mathrm{BOD}_{5}$, the concentration level exceeded $120 \mathrm{mg} / \mathrm{l}$ which is above of that permitted by the National Water Law in Mexico [15]. This is a clear indication of highly-polluted water due to municipal and domestic wastewater discharge under no environmental regulation (Figure 3(a)). Likewise, low dissolved oxygen concentrations (DO) in the range of 0.0 to $2.1 \mathrm{mg} / \mathrm{l}$ were measured, reflecting the anaerobic/anoxic condition. A high load of phosphorus $(\mathrm{P})$ and ammonia $\left(\mathrm{NH}_{4}\right)$ was also registered throughout the sampling points (Figure 3(b)).

Salinity values were found to be above 35,000 ppm (average sea salinity level) in four out of nine monitoring stations. The higher concentrations were encountered at the stations near the industrial area of "Dos Bocas", having between 42,000 and 50,000 ppm (Figure 4). In the case of total coliforms and heavy metals, the measured values were also found to be above the maximum permissible levels (Figure 5 and Table 2). 


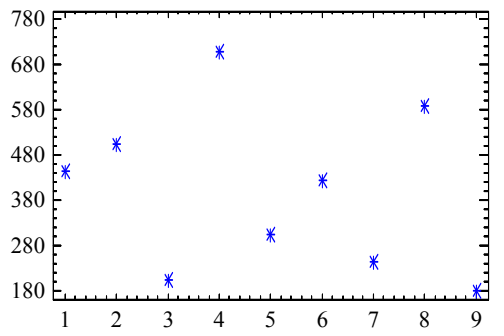

(a)

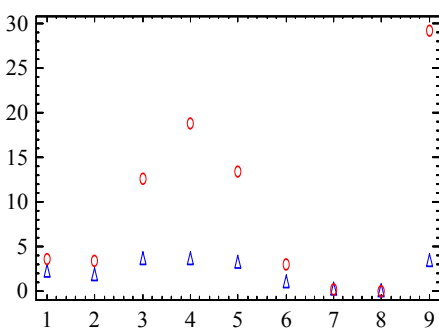

(b)

Figure 3: Measurements of $\mathrm{BOD}_{5}$ (a) and $\mathrm{P} / \mathrm{NH}_{4}$ (b) concentrations (mg/l).
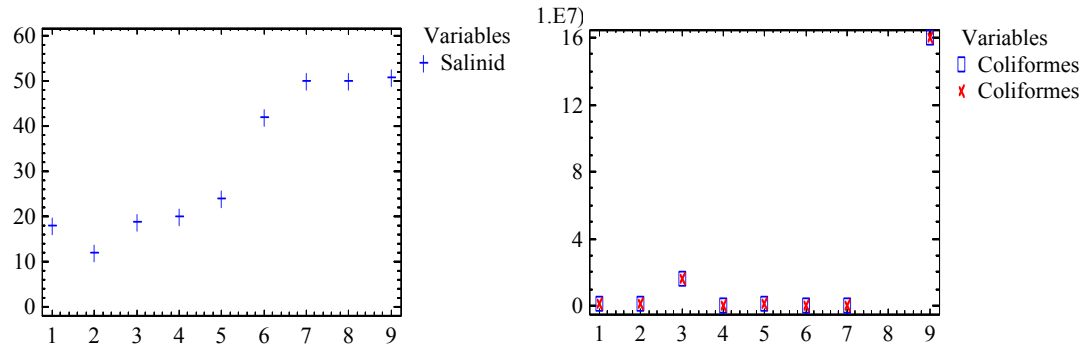

Figure 4: Salinity values $\left(10^{3} \mathrm{ppm}\right)$. Figure 5: Total coliforms (MPN /100 mg/l).

Table 2: $\quad$ Measured heavy metal concentrations vs. NOM-001-ECOL-1996.

\begin{tabular}{|c|c|c|c|c|c|}
\hline \multirow[t]{2}{*}{ Heavy Metal } & \multicolumn{2}{|c|}{$\begin{array}{c}\text { Measured } \\
\text { concentration }(\mathrm{mg} / \mathrm{l})\end{array}$} & \multicolumn{3}{|c|}{$\begin{array}{c}\text { NOM-001-ECOL-1996 } \\
\text { Maximum permissible limits (mg/l) } \\
\end{array}$} \\
\hline & Minimum & Maximum & $\begin{array}{l}\text { Agricultural } \\
\text { irrigation }\end{array}$ & $\begin{array}{c}\text { Urban } \\
\text { areas }\end{array}$ & $\begin{array}{l}\text { Aquatic life } \\
\text { protection }\end{array}$ \\
\hline Arsenic (As) & 0.08 & 0.16 & 0.2 & 0.1 & 0.1 \\
\hline Cadmium (Cd) & 0.14 & 0.38 & 0.2 & 0.1 & 0.1 \\
\hline Copper $(\mathrm{Cu})$ & 2.27 & 53.18 & 4 & 4 & 4 \\
\hline Total Cromium $(\mathrm{Cr})$ & 1.38 & 7.864 & 1 & 0.5 & 0.5 \\
\hline Nickel (Ni) & 6.78 & 13.40 & 2 & 2 & 2 \\
\hline Mercury (Hg) & - & - & 0.01 & 0.005 & 0.005 \\
\hline Lead $(\mathrm{Pb})$ & 2.51 & 28.59 & 0.5 & 0.2 & 0.2 \\
\hline Zinc $(\mathrm{Zn})$ & 19.06 & 313.37 & 10 & 10 & 10 \\
\hline
\end{tabular}

According to its structure, Seco River is considered to be a first order watershed since the water stream continuously runs at all times and does not have tributaries. To the northwest $(\mathrm{NW})$, the superficial stream communicates 
with the continental lake "Las Flores" which, in turn, links to the sea area through a tidal flow (Figure 6).

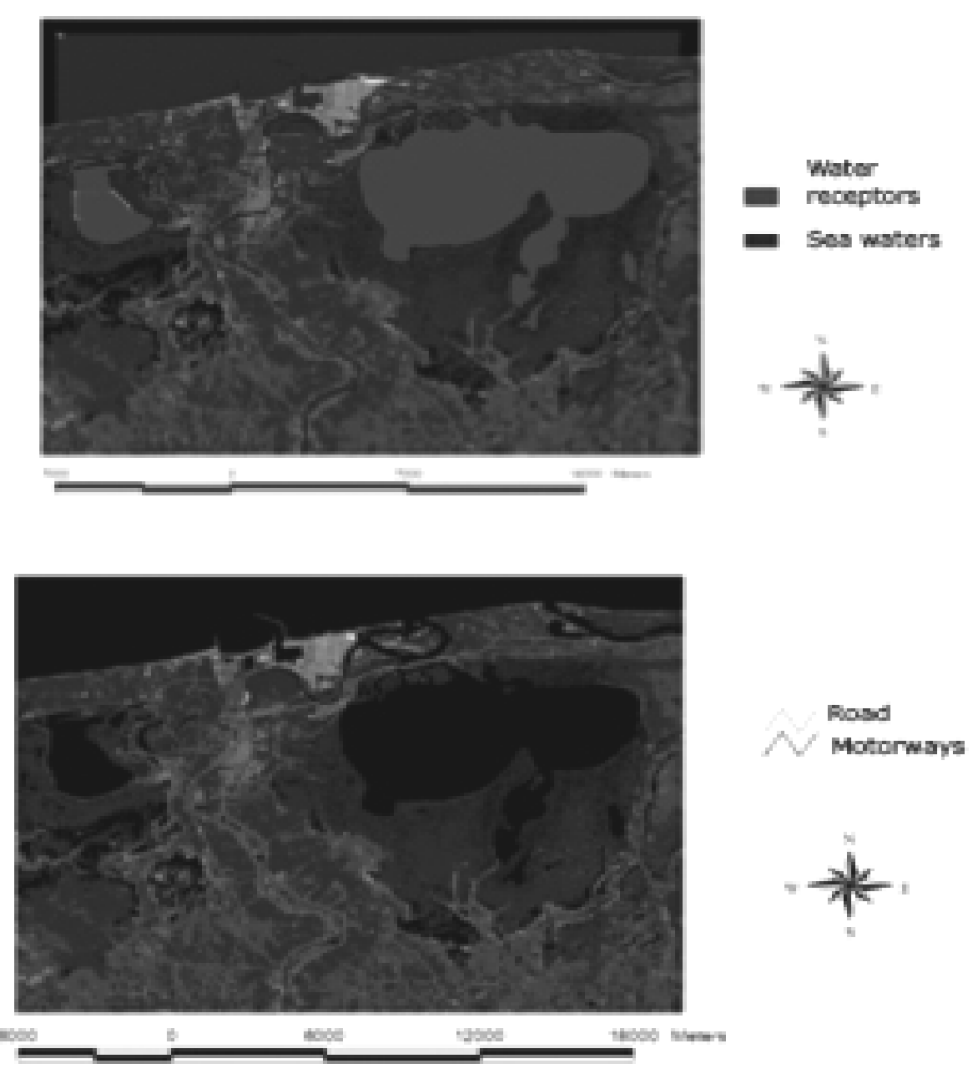

Figure 6: Images of the main water receptors and roads.

The measurement results of the maximum isolation distance from 0 to 7,660 $m$ regarding the Seco River and, accordingly to the IDRISI model, can be seen in Figures 7(a) and 7(b). The analysis of the maximum isolation distance provided an initial scale range from 0 to $1,500 \mathrm{~m}$ until it reaches $7,660 \mathrm{~m}$ which is the limit setup in the model (Figure 7(c)).

The model results allowed to defining a micro-watershed in the Seco River and the environmental factors affecting it. This micro-watershed shows a consistent water flow condition over other water receptors, remaining without changes for the period 2000-2003. Based on the obtained distances, there is no loss of continuity between Las Flores and Mecoacan Lakes (Figure 8). The shown vectors in Figure 9 identify the urban skirts of the population centre, where significant changes may be observed for housing establishment (Figure 9). 


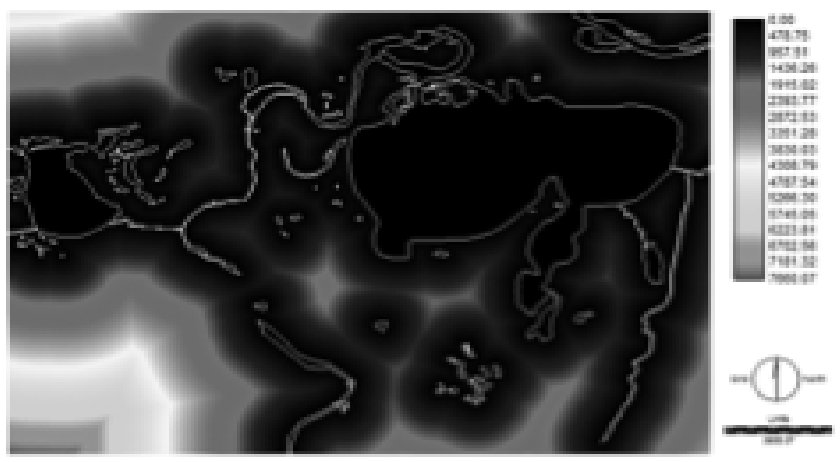

(a)

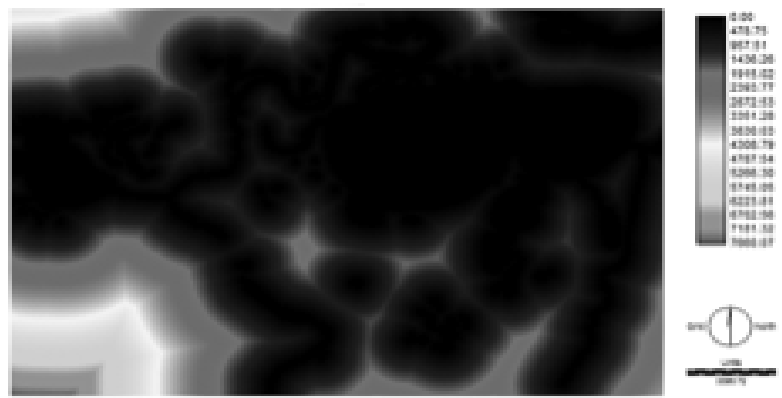

(b)

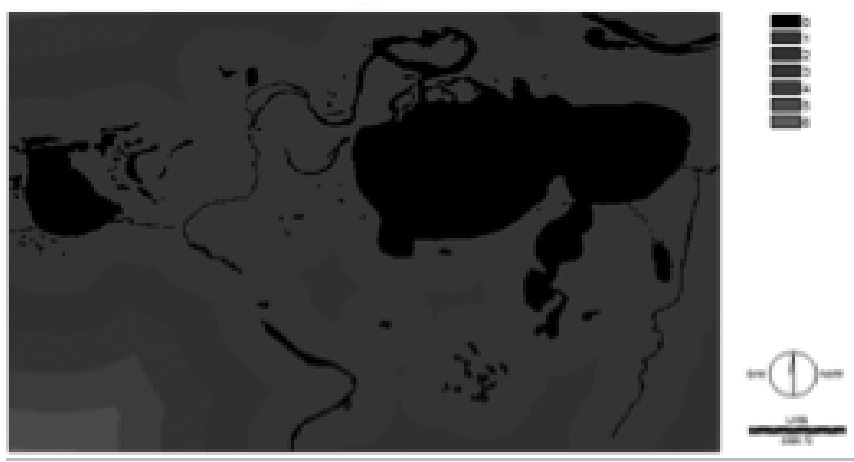

(c)

Figure 7: Definition of the maximum isolation distances for the year 2000 and 2003 (0 to 7,660 m) in the Seco River modeled with IDRISI. 


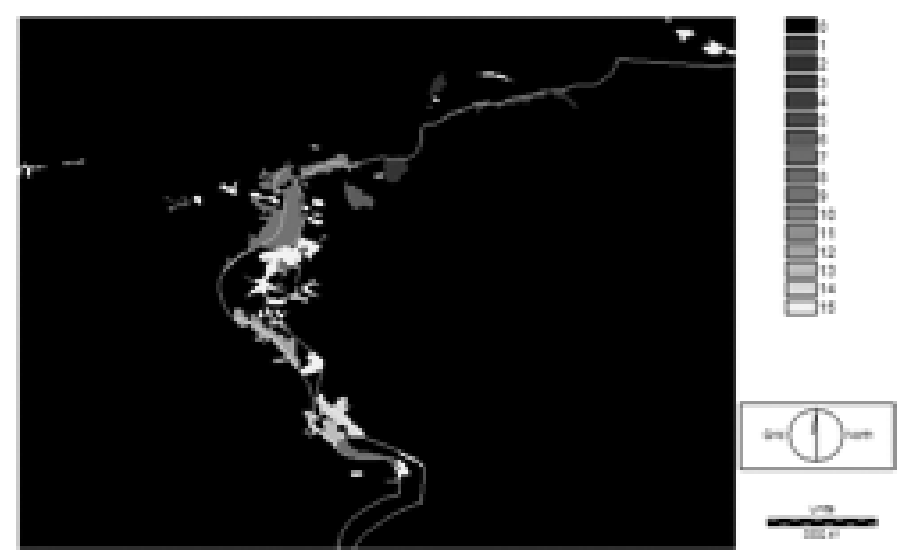

Figure 8: Urban skirts and roads at the Seco River.
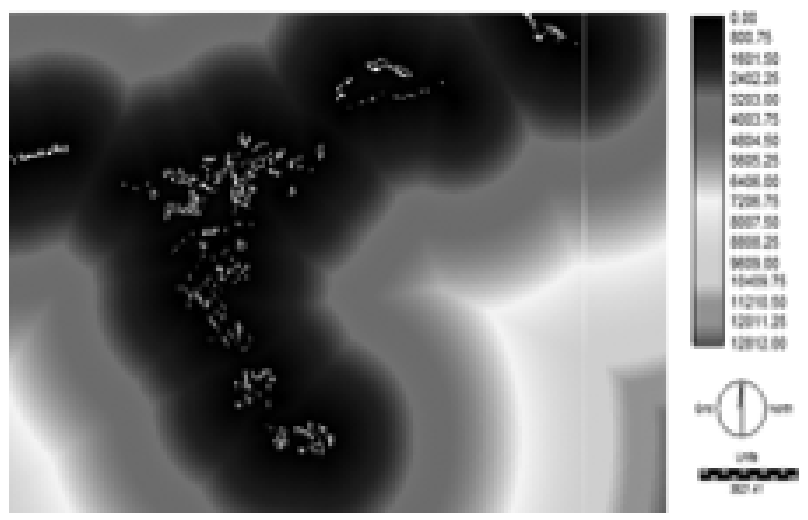

Figure 9: Growing areas for the years 2000 and 2003.

For the period 2000-2003, the GIS application to the LANDSAT images enabled the classification of environmental aspects which integrate the microwatershed and its geographic location. Figures 10-13 show the model results found for water receptors, urban growing, roads, coconut plantations, green grass and mangroves. 

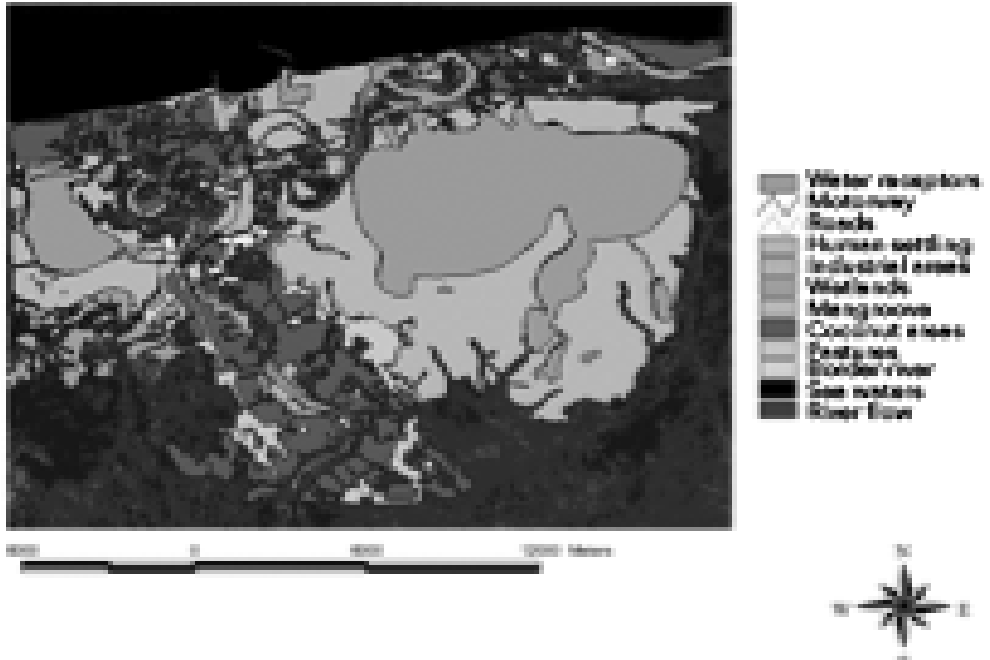

Figure 10: $\quad$ Image for the year 2000.

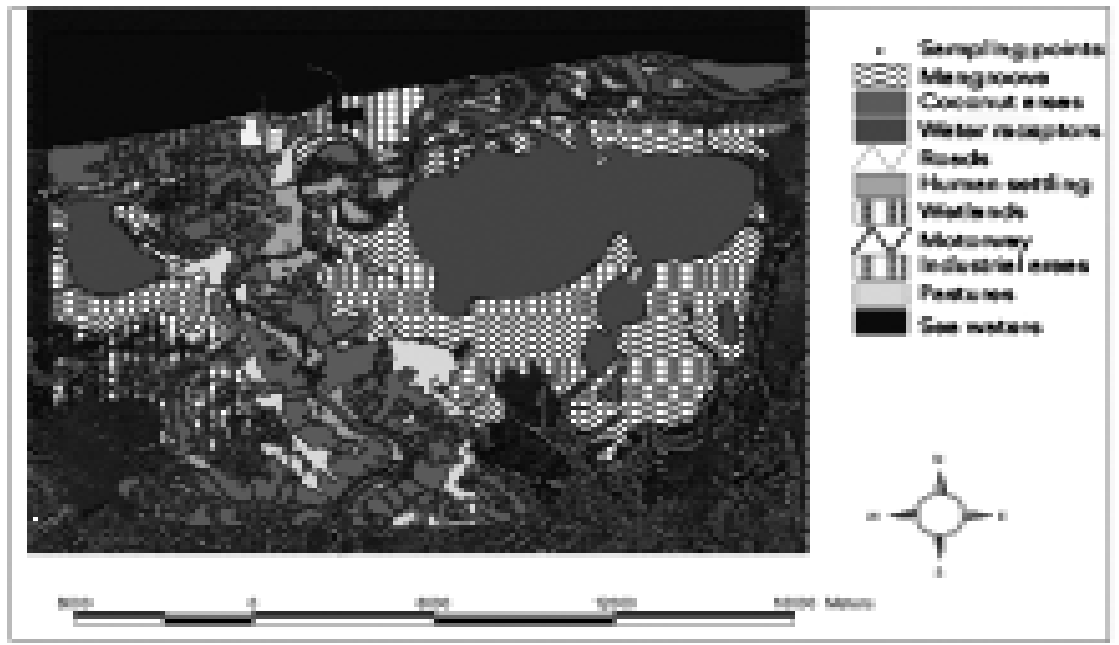

Figure 11: Image for the year 2002. 


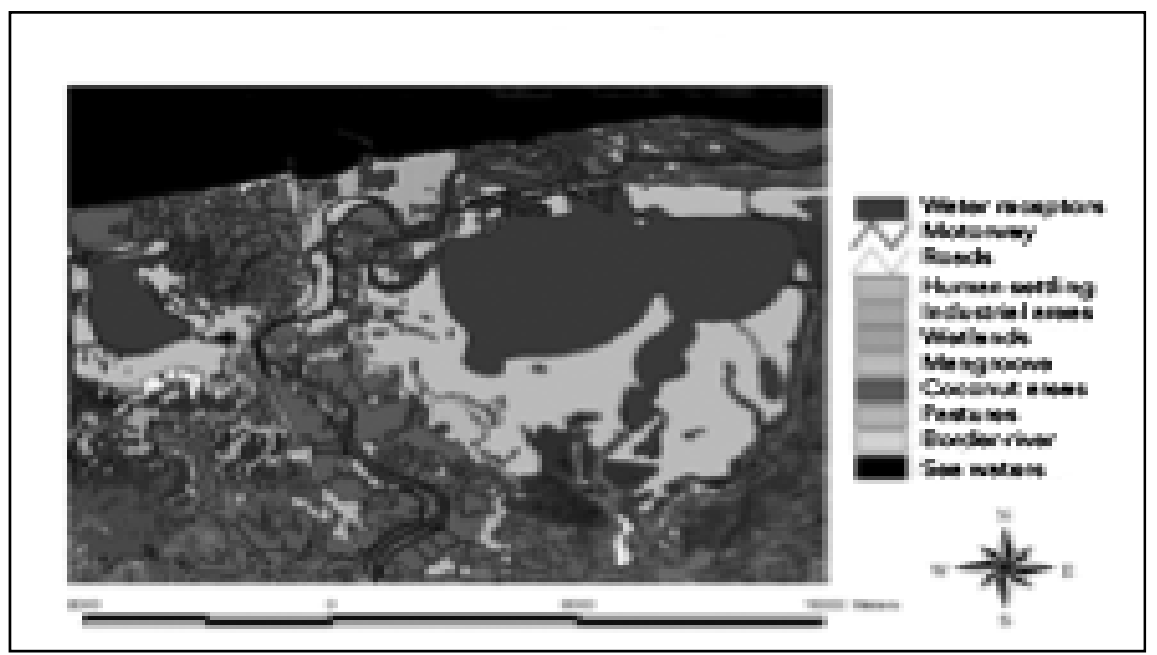

Figure 12: $\quad$ Image for the year 2003.

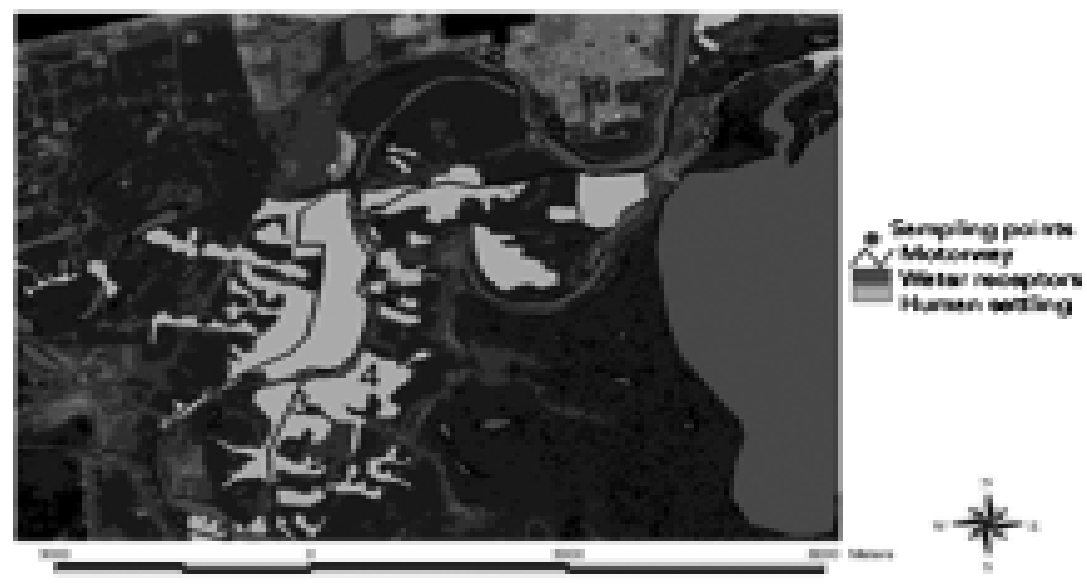

Figure 13: Location of sampling points.

On the other hand, the generated maps show the hydrologic conditions of the system and the environmental factors affecting the behavior of the microwatershed at the Seco River for the years 2000, 2002 and 2003 (Figure 15). Likewise, a loss of various kinds of vegetation and biodiversity can be observed because of the unregulated urban growing, as well as the soil use changing in substitution of green grass by fruit areas. 


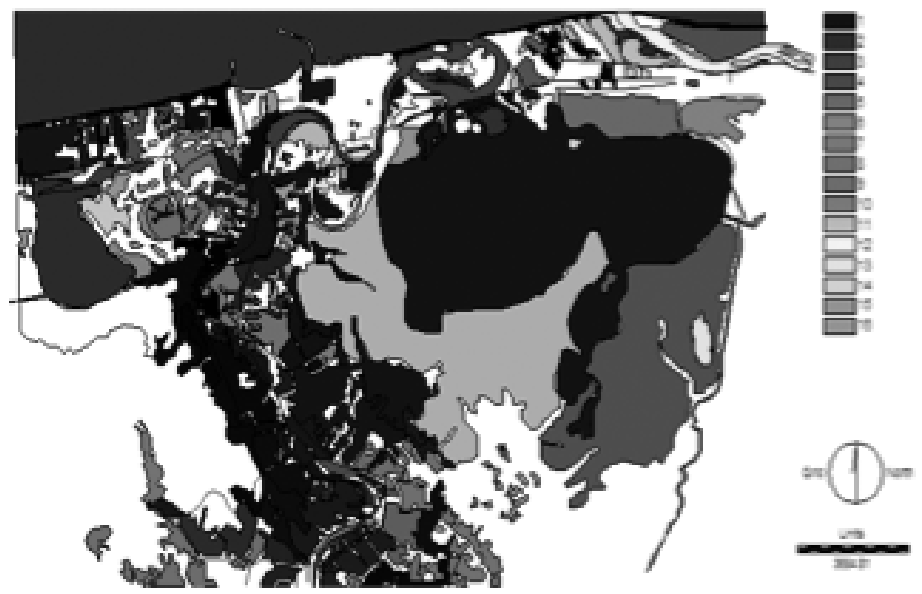

Figure 14: Classified and identified vectors for the years 2000, 2002 and 2003.

From the modeling and field results, the Seco River was found to be seriously affected by the urban growth, loss of coconuts and loss of mangrove population. Hence the lack of vegetation allowed for a significant amount of sediment dragging into the Seco River during pluvial run-off. This, in turn, increased the turbidity and diminished not only the DO in the water but also its depth. Consequently, the water temperature is expected to rise since the solar light easily penetrates along the water column. In this context, the main socioenvironmental characteristics of the Seco River were obtained in terms of biodiversity, ecosystems, environmental services and production systems. Hence a solution matrix may be proposed for an environmental restoration of the Seco River and a management state program in the short-term (Table 3).

\section{Conclusions}

The aquatic environmental ecosystem of the Seco River shows a high degree of contamination according to the Mexican environmental legislation. The main cause of such contamination is due to the uncontrolled discharges of municipal and domestic wastewater sources. The current modeling results showed that urban growth, coconut loss and loss of mangrove population are the major contributors.

The highly-contaminated Seco River may be reversible if appropriate environmental restoration programs are applied. The environmental directives should be resting on the environmental model results which are based on physicochemical data and geographical information systems. In time, the systematic evaluation of historical images will give rise to future environmental sceneries through well-probed environmental/ecological models (i.e., IDRISI). 
Table 3: Matrix of socio-environmental issues at the Seco River.

\begin{tabular}{|c|c|c|c|c|}
\hline MAIN THEME & AREA & PROBLEMS & CAUSE & $\begin{array}{l}\text { POSSIBLE } \\
\text { SOLUTION }\end{array}$ \\
\hline BIODIVERSITY & BIOLOGICAL & $\begin{array}{l}\text { Degradation. } \\
\text { Extinction. }\end{array}$ & $\begin{array}{l}\text { Loss of habitat. } \\
\text { Over- } \\
\text { exploitation. }\end{array}$ & $\begin{array}{l}\text { Biological } \\
\text { Conservation. }\end{array}$ \\
\hline $\begin{array}{l}\text { ENVIRONMENTAL } \\
\text { SERVICES }\end{array}$ & $\begin{array}{c}\text { WATER } \\
\text { RECEPTORS }\end{array}$ & $\begin{array}{l}\text { Low water } \\
\text { quality. } \\
\text { Climate } \\
\text { change. }\end{array}$ & $\begin{array}{l}\text { Water } \\
\text { contamination. } \\
\text { Urban growth. }\end{array}$ & $\begin{array}{l}\text { Wastewater } \\
\text { treatment. } \\
\text { Urban planification. }\end{array}$ \\
\hline $\begin{array}{l}\text { PRODUCTION } \\
\text { SYSTEMS }\end{array}$ & AGROINDUSTRY & $\begin{array}{l}\text { Soil use } \\
\text { changing. } \\
\text { Pesticides. }\end{array}$ & $\begin{array}{l}\text { Diminished } \\
\text { agricultural } \\
\text { areas. } \\
\text { Lethal yellowish. }\end{array}$ & $\begin{array}{l}\text { Mixed plantations } \\
\text { and germoplasm } \\
\text { reproduction. }\end{array}$ \\
\hline $\begin{array}{l}\text { THREATENED } \\
\text { SPECIES }\end{array}$ & $\begin{array}{c}\text { LOSS OF } \\
\text { BIODIVERSITY }\end{array}$ & $\begin{array}{c}\text { Species } \\
\text { ending. } \\
\text { Uncontrolled } \\
\text { deforestation. }\end{array}$ & $\begin{array}{l}\text { Species under } \\
\text { stress. } \\
\text { Mangrove use } \\
\text { for carbon. } \\
\text { Clandestine } \\
\text { manufacture. }\end{array}$ & $\begin{array}{l}\text { Species } \\
\text { conservation. } \\
\text { Productive } \\
\text { development of } \\
\text { projects for the } \\
\text { community. }\end{array}$ \\
\hline $\begin{array}{l}\text { SPECIES AND } \\
\text { ECOSYSTEMS }\end{array}$ & CONSERVATION & $\begin{array}{l}\text { Few habitats. } \\
\text { Diminution of } \\
\text { water depth. }\end{array}$ & $\begin{array}{l}\text { Growth. } \\
\text { Deforestation. } \\
\text { Sediments in } \\
\text { excess due to } \\
\text { run-off. }\end{array}$ & $\begin{array}{l}\text { Initiative of } \\
\text { environmental } \\
\text { justice. } \\
\text { Environmental } \\
\text { restoration. } \\
\text { Reforestation. }\end{array}$ \\
\hline $\begin{array}{l}\text { TRADITIONAL } \\
\text { KNOWLEDGE }\end{array}$ & SOCIAL & $\begin{array}{l}\text { Demographic } \\
\text { growth. } \\
\text { Pollutant } \\
\text { activities. }\end{array}$ & $\begin{array}{l}\text { Demographic } \\
\text { inmigration. } \\
\text { Industrial } \\
\text { services. } \\
\text { PEMEX. }\end{array}$ & $\begin{array}{l}\text { Control of } \\
\text { population. } \\
\text { Environmental } \\
\text { legislation. }\end{array}$ \\
\hline $\begin{array}{l}\text { SUSTAINABLE } \\
\text { DEVELOPMENT }\end{array}$ & ECONOMY & $\begin{array}{c}\text { Few } \\
\text { productive } \\
\text { works. } \\
\text { Lack of } \\
\text { professional } \\
\text { courses. }\end{array}$ & $\begin{array}{l}\text { Deforestation. } \\
\text { Urban growth. } \\
\text { Temporal and } \\
\text { permanent } \\
\text { employment } \\
\text { demand. }\end{array}$ & $\begin{array}{l}\text { Promotion of } \\
\text { ecotourism. } \\
\text { Reforestation. } \\
\text { Cleaning of urban } \\
\text { areas. }\end{array}$ \\
\hline
\end{tabular}

In the short-term, an integrated environmental plan together with a fundamental educative model should be compulsory for the social organization and participation of all citizens focusing on sustainability. The local and state government will have to produce the right mechanisms or programs in order to achieve the above objectives.

\section{References}

[1] Aguilera, G. (1977) Contribución al conocimiento hidrológico de la Laguna Mecoacán, Puerto Ceiba, Tabasco. Tesis profesional. Universidad Autónoma de Baja California. Ensenada B.C. México, 83 p.

[2] López-Hernández, E.S., Maldonado, F., Sánchez-Munguía, A. (1997) Diagnóstico y evaluación del impacto ambiental en comunidades bióticas de los sistemas lagunares costeros Mecoacán y Carmen-Pajonal- Machona. 
Universidad Juárez Autónoma de Tabasco. Villahermosa, Tabasco. México, $71 \mathrm{p}$.

[3] Villanueva, M.J. (2008) Microcuencas, Universidad Autónoma Chapingo. México. Primera 2002, 222 p.

[4] Gómez, A., Reséndez, A. (1986) Notas sobre la hidrología del sistema de Lagunas costeras Carmen-Machona-Redonda, Tabasco, 1976-1980. Universidad Juárez Autónoma de Tabasco. Rev. Int. Universidad y Ciencia, 3(6):5-10, México.

[5] Vincent, M. (2001) Development implementation and analysis of Tampa Bay Coastal Prediction System. University of South Florida, St. Petersburg, Fl. USA, 252 pp.

[6] Margni, M., Pennington, W., Bennett, D.H., Jolliet, O. (2004) Cyclic exchanges and level of coupling between environmental media: Intermedia feedback in multimedia fate models. Environmental Science \& Technology/ Vol. 38, No. 12.5450-5457.

[7] Norma Oficial Mexicana NOM-001-ECOL-1996, que establece los límites máximos permisibles de contaminantes en las descargas de aguas residuales en aguas y bienes nacionales. Normas Técnicas Mexicanas de Aguas Residuales en México. Diario Oficial de la Federación (30/04/1997).

[8] Hach Company (1997) World Headquarters. DR/2010 procedures manual. Loveland, Colorado, $872 \mathrm{p}$.

[9] APHA, AWWA, WPCF (1994) Standard Methods for the Examination of Water and Wastewater. 19th Edition, USA.

[10] Parker, S. P., and R. A. Corbitt. 1993. Encyclopedia of Environmental Science \& Engineering. 3rd Edition. McGraw Hill. Willard, Ohio. 749 p.

[11] Labsun bio-instrument Co., Ltd. (2011) www.szlabsun.com/en/

[12] Dimov, L.N. (2002) Implementing GIS to resolve environmental coastal problems in Varna. Environmental Protection Technology for Coastal Areas. III. Water Science and Technology. Vol 46, No. 8. 161-167 pp.

[13] Dobosiewicz, J. F., Ngoy, K. I. (2005) Assessment of shoreline stabilization using digital orthography global positioning systems and GIS. Department of Geology and Metereology, Kean University. PP 11. NOAA Coastal services center, Charleston, SC, USA.

[14] Gann, D. (2007) A mix of old and new; Kachemak bay research historic erosion rates mapping projects. Coastal geotools 07. P.63. NOAA Coastal Service Center. Charleston SC, USA.

[15] CONAGUA (2007) Comisión Nacional del Agua. Manual de agua potable, alcantarillado y saneamiento. Gerencia de proyectos de agua potable, alcantarillado y saneamiento, México, D.F. 